http://ejurnal.ubharajaya.ac.id/index.php/EDUKARYA

\title{
Keefektifan Pembelajaran Project Based Learning terhadap Sikap Ilmiah pada Mahasiswa PGSD
}

\author{
Arief Cahyo Utomo ${ }^{1 *}$, Zaenal Abidin' ${ }^{2}$ Henry Aditya Rigiyanti ${ }^{3}$ \\ 1,2Pendidikan Guru Sekolah Dasar, Fakultas Keguruan dan Ilmu Pendidikan, Universitas \\ Muhammadiyah Surakarta, Jl. A. Yani Tromol Pos 1, Mendungan, Pabelan, Kec. Kartasura, \\ Kabupaten Sukoharjo, Jawa Tengah, 57162, Indonesia \\ ${ }^{3}$ SDN Pucang, Banjarnegara, Indonesia \\ e-mail: ${ }^{1}$ acu234@ums.ac.id, ${ }^{2}$ za825@ums.ac.id, ${ }^{3}$ henry.aditia@ gmail.com \\ *Korespondensi e-mail: acu234@ums.ac.id
}

\begin{abstract}
Scientific attitudes are essential for students to improve their creative and critical thinking skills. In fact, there are still many learning practices that focus on lecturers. Learning methods are still widely used in learning one of them is expository. Whereas Expository method is a less effective method to improve the scientific attitude of students. Students will not be able to be scientific if they are not trained for such. To improve the scientific stance, the relevant learning methods are required. One of them is PJBL, a student-centered learning method. The advantages of PJBL learning are learning approaches that use critical thinking like revealing facts. This research was conducted to improve the attitude of students. The research method implemented is the action research model Kurt Lewin. With research procedure in 1 cycle is planning, application, observation, and reflection. The implementation was conducted for 2 cycles with 4 learning meetings. The results gained in this study were scientific attitudes of the students that were seen from the indicators of scientific attitudes have increased. The average increase of each student has reached $85 \%$. So it can be concluded that the implementation of PJBL in improving student scientific attitudes is said to be effective.
\end{abstract}

Keywords: PJBL, scientific stance, science.

Sikap ilmiah sangatlah penting bagi mahasiswa untuk meningkatkan kemampuan berpikir kritis dan kreatif. Pada kenyataannya masih banyak praktek pembelajaran yang berpusat pada dosen. Metode pembelajaran yang masih banyak digunakan dalam pembelajaran salah satunya adalah ekspositori. Padahal metode ekspositori merupakan metode yang kurang efektif untuk meningkatkan sikap ilmiah mahasiswa. Mahasiswa tidak akan dapat bersikap ilmiah jika mereka tidak dilatih untuk seperti itu. Untuk meningkatkan sikap ilmiah tersebut maka diperlukan metode pembelajaran yang relevan. Salah satunya adalah PJBL yaitu metode pembelajaran yang berpusat pada mahasiswa. Kelebihan pembelajaran PJBL adalah pendekatan pembelajaran yang menggunakan pemikiran kritis seperti mengungkap fakta-fakta. Penelitian ini dilaksanakan untuk meningkatkan sikap ilmih mahasiswa. Metode penelitian yang dilaksanakan yaitu action research model kurt lewin. Dengan prosedur penelitian dalam 1 siklus adalah perencanaan, penerapan, observasi, dan refleksi. Pelaksanaan dilakukan selama 2 siklus dengan 4 pertemuan pembelajaran. Hasil yang didapatkan dalam penelitian ini yaitu sikap ilmiah mahasiswa yang dilihat dari indikator-indikator sikap ilmiah mengalami kenaikan. Kenaikan rata-rata setiap mahasiswa sudah mencapai $85 \%$. Sehingga dapat disimpulkan bahwa penerapan PJBL dalam meningkatkan sikap ilmiah mahasiswa dikatakan efektif.

Kata kunci: PJBL, Sikap Ilmiah, IPA 


\section{PENDAHULUAN}

Dalam suatu perkuliahan apabila dosen mampu mengelola kelas dengan baik maka perkuliahan akan mudah di serap dan di pahami oleh mahasiswa. Selain itu kebutuhan mahasiswa selama mengikuti proses perkuliahan di dalam maupun di luar kelas dapat terpenuhi dengan baik. Suatu perkuliahan yang baik akan memberikan dampak yang baik pula seperti halnya mahasiswa dapat memecahkan soal. Akan tetapi dalam suatu proses perkuliahan akan muncul permasalah-permasalahan yang akan dihadapi salah satu permasalah perkuliahan yang muncul adalah motivasi belajar mahasiswa rendah dan hasil belajarnya juga demikian. Ketika peneliti melakukan observasi dalam pembelajaran IPA di perguruan tinggi Universitas Muhammadiyah Surakarta khususnya pada Program Studi Pendidikan Guru SD (PGSD) sikap ilmiah mahasiswa di kelas tersebut masih sangat rendah. Berdasarkan penilaian yang dilakukan menggunakan lembar observasi sikap ilmiah mahasiswa, diketahui bahwa sekitar 79,31\% mahasiswa di kelas tersebut kurang menunjukkan sikap ilmiah. Selama pembelajaran berlangsung, rasa ingin tahu, sikap berpikir kritis, respek terhadap data/fakta, sikap berpikiran terbuka dan kerjasama, serta ketekunan masih sangat rendah. Dari aspek rasa ingin tahu, terbukti ketika dosen memberikan sebuah pertanyaan kepada mahasiswa, hanya ada 8 mahasiswa yang antusias untuk mencari jawaban, sedangkan 21 mahasiswa lainnya hanya diam dan mendengarkan, tidak ada itikad untuk mencari jawaban dari pertanyaan yang diberikan oleh guru.

Selain rasa ingin tahu, sikap berpikir kritis siswa juga masih sangat rendah. Hal ini ditunjukkan oleh sikap mahasiswa ketika terdapat jawaban yang berbeda dari tugas yang diberikan oleh guru. Hanya 6 mahasiswa yang mempertanyakan perbedaan tersebut, 23mahasiswa lainnya tidak merespon hal itu. Mereka terkesan tidak peduli. Hal ini dikarenakan mereka tidak mau/malas untuk mencari tahu alasan perbeedaan jawaban tersebut. Sikap respek terhadap data juga terlihat rendah. Hal ini terbukti ketika mahasiswa mendapatkan tugas untuk dikerjakan secara berkelompok. Terdapat 13 mahasiswa yang dengan sungguh-sungguh mengerjakan tugas tersebut sesuai kemampuannya, sedangkan 16 mahasiswa yang lainnya asyik mencontoh jawaban dari kelompok lain.

Sikap berpikiran terbuka dan bekerjasama mahasiswa di kelas tersebut juga masih tendah. Hal ini ditunjukkan ketika guru membentuk kelas tersebut menjadi beberapa kelompok untuk melakukan diskusi. Dari 43 mahasiswa yang mengikuti pembelajaran IPA, hanya ada 8 mahasiswa yang aktif dalam kegiatan diskusi. Sedangkan 35 siswa yang lainnya masih sangat pasif, partisipasi mahasiswa dalam kegiatan tersebut masih sangat kurang. Begitu juga sikap ketekunan mahasiswa. Rendahnya ketekunan mahasiswa terlihat dari sikap mahasiswa ketika mengerjakan tugas yang diberikan oleh dosen. Terdapat 10 mahasiswa yang mau menyelesaikan tugas meskipun kelompok lain sudah selesai lebih awal. Sedangkan 33 mahasiswa di kelas tersebut tidak mau mengerjakan lagi apabila kelompok lain sudah selesai mengerjakan.

Rendahnya sikap ilmiah mahasiswa dalam pembelajaran IPA dikarenakan pembelajaran masih berpusat pada dosen. dosen hanya melakukan ceramah, melihat buku teks, kemudian dilanjutkan dengan pembahasan secara verbal. Dalam pembelajaran tidak ada kegiatan percobaan atau bentuk pembelajaran konkret lainnya yang dapat meningkatkan sikap ilmiah siswa. Pada akhir pembelajaran, penilaian yang dilakukan oleh dosen hanya berpusat pada aspek kognitif (penguasaan materi), sedangkan penilaian pada aspek afektif (sikap ilmiah) kurang diperhatikan 
Sikap ilmiah sangat penting bagi mahasiswa dalam belajar sains. Sikap ilmiah dapat digunakan mahasiswa untuk menentukan seberapa baik sikap mereka dalam melaksanakan keterampilan proses sains dalam pembelajaran. IPA yang mencakup sikap ingin tahu, respek terhadap fakta, berpikir kritis, penemuan dan kreativitas, berpikiran terbuka dan kerjasama ketekunan, dan sikap peka terhadap lingkungan sekitar. Sikap ingin tahu mendorong akan penemuan sesuatu yang baru dengan berpikir kritis akan meneguhkan pendirian dan berani untuk berbeda pendapat.

Beberapa metode pembelajaran antara lain pembelajaran dengan menggunakan metode Prolem based learning, Project based learning. Inquiry dan Discovery. Dalam kegiatan perkuliahan metode tersebut dapat membuka peluang kepada mahasiswa sumber belajar seperti informan dari buku, internet, koran, dan referensi dari perpustakaan yang telah disiapkan. Pada metode proyek, mahasiswa dapat memanfaatkan sumber belajar diluar kelas. Dianjurkan pula untuk materi tertentu mahasiswa memanfaatkan sumber belajar disekitar lingkungan masyarakat. Berdasarkan teori dan temuan penelitian sebelumnya, menggunakan metode Project based learning dalam perkuliahan dapat meningkatkan sikap ilmiah mahasiswa sehingga metode ini diyakini menjadi metode yang paling efektif. Hal ini dikarenakan pada perkuliahan Project based learning mahasiswa akan tertarik dan tidak merasa bosan dengan kegiatan memecahkan permasalahan sekitar. Oleh karena itu pembelajaran dengan menggunakan metode Project based learning lebih meningkatkan sikap ilmiah mahasiswa, kama pembelajaran berbasis proyek dapat meningkatkan sikap ilmiah mahasiswa. Hal ini sejalan dengan pendapat (Bos, 2011) bahwa ketika guru berhasil menerapkan metode Project based learning individu maupun kelompok mahasiswa dapat sangat termotivasi, merasa aktif terlibat dalam pembelajaran mereka sendiri.

\section{A. Model Project based learning}

Pembelajaran proyek adalah pembelajaran yang autentik. Yang melibatkan kenyataan, keterbukaan dan menghargai proyek yang dilakukan siswa. Pembelajaran proyek juga menyediakan ketertarikan dan produktivitas pengalaman belajar. PJBL merupakan model pembelajaran yang berpusat pada siswa, yang dipastikan siswa mengembangkan pengetahuan dan ketrampilan secara spesifik. Melalui tugas yang inkuiri dan praktik yang sebenarnya yang berorientasikan hasil belajar. (Muresan,2014; E. Lake, 1997; Harteseu,2014; Pickens, et al, 2012; Boric,2007; Hosnan,2014)

Santrock (2009) menyatakan bahwa melalui belajar dengan proyek siswa berupaya untuk menghasilkan produk dalam menyelesaikan masalah. Lebih lanjut dikemukakan oleh Bender (2012) bahwa project based lerning adalah model isntruksional yang berbasis pada pembelajaran isu-isu dan proyek yang mereka kerjakan dapat menghantarkan mereka pada kepemahaman serta kegiatan untuk memecahkan permasalahan.

\section{B. Tujuan Model Project based learning}

Manfaat project based learning di antaranya adalah sebagai berikut:

1) Memperoleh pengetahuan dan keterampilan baru dalam pembelajaran.

2) Meningkatkan kemampuan peserta didik dalam pemecahan masalah.

3) Membuat peserta didik lebih aktif dalam memecahkan masalah yang kompleks dengan hasil produk nyata berupa barang atau jasa.

4) Mengembangkan dan meningkatkan keterampilan peserta didik dalam mengelola sumbcr/bahan/alat untuk menyelesaikan tugas.

5) Meningkatkan kolaborasi peserta didik khususnya pada PJBL yang bersifat 
kelompok.

C. Langkah-langkah Model Project Based /canting

Langkah-langkah ini telah dijelaskan oleh (Satrianawati,2014; Bender, 2012)yaitu sebagai berikut:

1) Penentuan pertanyaan mendasar atau lebih dikenal dengan driving question. Pertanyaan ini menentukan arah dan tujuan yang harus dilakukan peserta didik untuk menghasilkan karya atau hasil belajar sebagai produk pembelajaran.

2) Menyusun perencanaan proyek atau devise plan. Rencana disusun untuk memudahkan penyelesaian atau pemecahan masalah.

3) Menyusun jadwal. Jadwal disusun dengan pertimbangan bahwa segala yang akan dilakukan harus ditentukan waktu pelaksanaannya agar semua tepat sasaran.

4) Memantau atau monitoring dilakukan ketika proses pengerjaan proyek.

5) Menguji hasil dilakukan setelah produk atau hasil karya telah diselesaikan oleh siswa.

6) Evaluasi lapangan dilakukan di lapangan atau menerapkan di tempat yang lain dengan fokus permasalahan yang sama sehingga diperoleh kelayakan, ketidak layakan atau perlu direvisi kembali produk yang telah diciptakan.

D. Kelebihan Model Project based learning

Westwood (2008 hlm 33-34) menjelaskan kelebihan dari project based learning adalah:

1) The project approach can be applied in almost all areas of the curriculum.

2) Projects have a 'real world' orientation and promote meaningful learning by connecting new information to students ' past experiences and prior knowledge.

3) Students learn valuable processes and skills for gathering and analysing data.

4) Students are responsible for their own learning, thus increasing self direction and motivation.

5) The learning process encourages various modes of communication and representation.

6) The approach encourages use of higher-order thinking as well as acquistion of facts.

7) The approach developes deeper knowledge of subject matter.

8) The approach also increases team-working and cooperative learning skills.

E. Kelemahan Model Project based learning

Sedangkan Kelemahan project based leaming berdasarkan kurikulum 2013 yang dikaji oleh Satrianawati, (2015, hlm. 502-503) yaitu:

1) Memerlukan banyak waktu untuk menyelesaikan masalah.

2) Membutuhkan biaya yang cukup banyak.

3) Banyak instruktur yang merasa nyaman dengan kelas tradisional, dimana instruktur memegang peran utama di kelas.

4) Banyaknya peralatan yang harus disediakan.

5) Peserta didik yang memiliki kelemahan dalam percobaan dan pengumpulan informasi akan mengalami kesulitan.

6) Ada kemungkinan peserta didik yang kurang aktif dalam kerja Kelompok

7) Ketika topik yang diberikan kepada masing-masing kelompok berbeda, dikhawatirkan peserta didik tidak bisa memahami topik secara keseluruhan. 


\section{F. Sikap Ilmiah IPA}

Salah satu aspek yang dikembangkan dalam pembelajaran IPA di sekolah adalah aspek sikap. Sikap berkembang dari interaksi antara individu dengan lingkungan masa lalu dan masa kini. Melaui proses kognisi dari integrasi dan konsistensi sikap dibentuk menjadi komponen kognisi, emosi, dan kecendrungan bertindak. Setelah sikap terbentuk akan mempengaruhi perilaku secara langsung. Perilaku akan memmpengaruhi pembahan lingkungan yang ada, dan perubahan- perubahan yang terjadi akan menuntun pada perubahan sikap yang dimiliki. Sikap adalah kecenderungan jiwa terhadap orang, obyek, subyek, peristiwa, dan sebagainya (Martin, 2005). Sikap sebagai kecenderungan untuk berpikir, merasa, memahami dan bersikap terhadap objek kognitif. Pemikiran tentang pembelajaran IPA melalui pengembangan sikap ilmiah merupakan alternatif yang sangat tepat berkenaan dengan pendidikan saat ini (Pitafi, 2012).

Salah satu sikap yang dikembangkan dalam pembelajaran IPA di sekolah dasar salah satunya penanaman sikap ilmiah dalam belajar. Harlen (2000) sikap ilmiah dikelompokkan menjadi dua yaitu: 1) seperangkat sikap yang menekankan sikap tertentu terhadap IPA sebagai suatu cara memandang dunia serta dapat berguna bagi pengembangan karir di masa mendalang, dan 2) seperangkat sikap yang jika diikuti akan membantu proses pemecahan masalah. Sikap ilmiah merupakan aturan perilaku yang ilmuwan lakukan ketika dalam penyelidikan ilmiah (Carin \& Sund 1987; Patta Bundu, 2006). Sikap ilmiah merupakan kemampuan untuk bereaksi secara konsisten, rasional, dan obyektif dengan cara tertentu dalam setiap permasalahan (Olasehinde, 2014).

\section{G. Aspek-aspek Sikap Ilmiah IPA}

Ranah sikap dalam pembelajaran IPA merupakan perwujudan dari nilai- nilai karakter yang selama ini dikembangkan dalam pembelajaran. Sikap ilmiah secara umum mengajarkan kepada siswa tentang berbagai sikap positif yang akan muncul manakala belajar IPA. Harlen (2000, hlm. 192) menjelaskan bahwa aspek- aspek sikap ilmiah, meliputi "curiosity, respectfor evidence, Flexibility in ways of thinking, critical reflection, sensitivity in investigating the environment" Rasa ingin tahu, menghargai bukti, fleksibilitas dalam cara berpikir, berfikir kritis, kepekaan dalam menyelidiki lingkungan sekitar.

Menurut Carin \& Sund (1987, hlm. 6) bahwa "aspek-aspek sikap ilmiah mencakup "curiosity, humility, skepticism, open-mindedness, avoidance of dogmatism or gullibility, positive approach to failure, objectivity." Sikap ingin tahu, kerendahan hati, skeptisisme, berfikir terbuka, menghindari dogmatisme atau mudah ditipu, pendekatan positif terhadap kegagalan, objektivitas. Sedangkan Pitafi (2012, hlm. 383) menjelaskan aspek sikap ilmiah terdiri: "curiosity, rationality, willingness to suspend judgment, open-mindedness, critical mindedness, objectivity, intellectual honesty, humility", rasa ingin tahu, rasionalitas, kesediaan untuk menunda penilaian, berpikir terbuka, berfikir kritis, objektivitas, kejujuran intelektual, kerendahan hati.

Sikap ilmiah digunakan siswa dalam melaksanakan keterampilan proses dalam pembelajaran. Menurut Martin (2005, hlm. 13), sikap ilmiah terdiri dua aspek, meliputi: "emotional attitudes and intellectual altitudes". Sikap emosional terdiri dari rasa ingin tahu yang lebih, ketekunan, pendekatan positif terhadap kegagalan, berfikir terbuka dan kerja sama dengan lainnya. Sedangkan sikap intelektual terdiri dari: 1) keinginan untuk mencari sumber informasi yang akurat, 2) skeptisisme, meragukan temuan yang 
diperoleh, 3) menghindari generalisasi secara luas ketika ditemukan bukti yang terbatas, 4) memiliki toleransi dari pendapat orang lain, penjelasan, atau pendapat, 5) kesediaan untuk menahan penilaian sampai semua bukti atau informasi yang ditemukan atau diperiksa, 6) menolak untuk percaya pada takhayul atau menerima klaim tanpa bukti, 7) keterbukaan untuk mengubah pikiran mereka ketika bukti yang diberikan dan terbuka terhadap pertanyaan tentang ide-ide mereka sendiri.

Aspek-aspek sikap ilmiah yang dikembangkan dalam pembelajaran IPA di sekolah dasar menurut Patta Bundu (2006, hlm. 141), antara lain:

1. Sikap ingin tahu, aspeknya meliputi: antusias mencari jawaban, perhatian pada objek yang diamati, antuasias proses IPA, dan menanyakan setiap langkah kegiatan.

2. Sikap respek terhadap fakta/ data, aspeknya meliputi: objektif/jujur, tidak berburuk sangka, mengambil keputusan sesuai dengan fakta dan tidak mencampur fakta dan pendapat.

3. Sikap berpikir kritis, aspeknya meliputi: meragukan temuan orang lain, menanyakan setiap perubahan, mengulangi kegiatan yang dilakukan, dan tidak mengabaikan data meskipun kecil.

4. Sikap penemuan dan kreativitas, aspeknya meliputi: menggunakan fakta-fakta untuk dasar kesimpulan, menunjukkan laporan berbeda dengan orang lain, merubah pendapat dalam merespon terhadap fakta menyarankan percobaan-percobaan baru, dan menguraikan kesimpulan-kesimpulan baru hasil pengamatan.

5. Sikap ilmiah terbuka dan kerjasama, aspeknya meliputi: menghargai pendapat temuan orang lain, mau merubah pendapat jika data kurang, menerima saran dari orang lain, tidak merasa selalu benar, menganggap setiap kesimpulan adalah tentative, dan berpartisipasi aktif dalam kelompok.

6. Sikap ketekunan, aspeknya meliputi: melanjutkan kebiasaaan meneliti, mengulangi percobaan meskipun berakibat kegagalan, dan melanjutkan satu kegiatan meskipun orang lain selesai lebih awal.

7. Sikap peka terhadap lingkungan sekitar, aspeknya meliputi perhatian terhadap peristiwa sekitar, partisipasi pada kegiatan sosial, menjaga kebersihan dan kelestarian lingkungan.

H. Faktor-faktor yang Mempengaruhi Sikap Ilmiah IPA

Menurut Martin (2005, hlm. 12) di dalam sains, sikap yang penting memiliki tiga faktor utama, yang meliputi: Pertama, sikap anak dapat membawa kesiapan dalam kondisi mental. Kedua, sikap bawaan atau sikap tidak dari bawaan. Ketiga, sikap adalah hasil pengalaman yang dinamis yang bertindak sebagai faktor penentu ketika anak memasuki pengalaman baru. Sikap ilmiah sangat penting bagi siswa dalam belajar sains. Sikap ilmiah dapat digunakan siswa untuk menentukan seberapa baik sikap mereka dalam melaksanakan keterampilan proses sains dalam pembelajaran. Menurut Osborne (2003, hlm. 106) faktor-faktor yang mempengaruhi sikap ilmiah, seperti: 1) Jenis kelamin: 2) Lingkungan kelas; 3) Guru; 4) Kurikulum; 5) Materi yang dirasakan sulit dalam sains. Sedangkan menurut Pitafi (2012, hlm. 382) Sikap tentang obyek dipengaruhi oleh persepsi individu terhadap diri, lingkungan sosial dan ide dari gagasan seseorang. Persepsi juga dipengaruhi oleh sikap.

\section{Cara Mengukur Sikap Ilmiah IPA}

Pengukuran sikap ilmiah didasarkan pada pengelompokan indikator- indikator sehingga memudahkan menyusun butir instrumen sikap ilmiah. Pengukuran sikap ilmiah 
IPA menggunakan metode observasi, wawancara, dokumentasi dan angket. Metode pengumpulan data menggunakan angket, karena angket hampir sama dengan wawancara tersuuktur. disamping itu angket tidak perlu saling berhadapan (face to fuce) antara penilai (guru) dengan yang dinilai (siswa). Hanya saja angket perlu disusun sebaik mungkin agar dapat menjaring semua informasi/data yang diperlukan karena pertanyaan dan jawaban tidak dapat diulangi. Instrumen yang digunakan adalah berupa skala Likert. Dalam penelitian ini. instrumen yang digunakan untuk mengetahui sikap ilmiah siswa adalah menggunakan lembar angket dengan menggunakan skala Likert dengan pilihan jawaban sangat setuju (SS), setuju (S), tidak setuju (TS), dan sangat tidak setuju (STS).

\section{J. Penelitian yang Relevan}

Pada dasarnya penelitian tidak beranjak dari nol, akan tetapi telah ada acuan yang mendasari atas penelitian yang sejenis. Oleh karena itu perlu mengenali penelitian relevan yang terdahulu antara lain:

Dari kesimpulan hasil penelitian terdahulu yang relevan, dapat digunakan untuk memperkuat sintesa teori dan temuan dari hasil penelitian ini. Pada dasarnya terdapat beberapa persamaan dan perbedaan antara penelitian yang relevan dengan penelitian ini. Persamaan terlihat pada sikap ilmiah yang ada pada mahasiswa pada mata kuliah pendidikan IPA SD. Menyikapi berbagai permasalahan yang telah diungkapkan dalam latar belakang masalah dan dalam upaya meninghatkan motivasi belajar perlu diadakan perbaikan pembelajaran dengan memanfaatkan strategi pembelajaran Project base learning pada kuliah pendidikan IPA SD kelas III/d PGSD UMS.

\section{METODE PENELITIAN}

Metode yang digunakan dalam penelitian ini adalah Classroom Action Research yaitu suatu Action Research (penelitian tindakan) yang dilakukan di kelas. Pelaksanaan tindakan kelas ini dilaksanakan berdasarkan perencanaan yang telah dibuat pada pembelajaran IPA melalui model pembelajaran Project Based Learning. Populasi penelitian tindakan ini yaitu seluruh mahasiswa angkatan 2016/2017. Kemudian diambil sample penelitian dengan metode simple random sampling. Dalam penelitian ini yang menjadi sample penelitian dosen pengampu matakuliah pendidikan IPA dan mahasiswa siswa kelas III D Program Studi Pendidikan Guru Sekolah Dasar (PGSD) sebanyak 43 mahasiswa. Berdasarkan observasi lingkungan penelitian, maka tempat yang menjadi sampel dalam penelitian adalah kelas III/d prodi PGSD UMS. Pelaksanaan Penelitian Tindakan Kelas ini dilaksanakan selama 2 bulan dimulai dari bulan Oktober 2016 sampai dengan november 2016. Pada bulan-bulan tersebut pembelajaran sangat aktif dan efektif sehingga memudahkan untuk dilakukan penelitian.

Prosedur Penelitian tindakan ini terdapat 4 tahapan yang pertama adalah tahap Perencanaan Tindakan hal ini meliput: (1) Mempersiapkan rencana pelaksanaan perkuliahan (RPP) (2) Merencanakan pembelajaran project based learning (3) Menyiapkan media dan sumber belajar yang relevan (4) Membuat Lembar Kerja (5) Membuat lembar observasi. (6) Membuat lembar evaluasi. Kemudiah tahap yang ke-2 adalah Pelaksanaan Tindakan hal ini meliputi: (1) Peneliti menerapkan pembelajaran IPA dengan menggunakan model pembelajaran project based learning, (2) Peneliti bersama dosen mitra mengisi pedoman observasi dan lembar observasi minat belajar untuk mengetahui proses dan hasil pembelajaran, tahapan yang ke-3 yaitu Observasi Tindakan Pada tahapan ini, peneliti melakukan pengamatan dan mencatat semua hal-hal yang diperlukan dan terjadi selama pelaksanaan tindakan berlangsung. Termasuk juga 
pengamatan secara cermat pelaksanaan skenario tindakan dari waktu ke waktu dan dampaknya terhadap proses dan hasil belajar siswa. Data yang dikumpulkan dapat berupa data kuantitatif (hasil tes, hasil kuis, presensi, nilai tugas, dan lain-lain), tetapi juga data kualitatif yang menggambarkan keaktifan siswa, antusias siswa, mutu diskusi yang dilakukan, dan lain-lain. Tahap yang teakhir adalah Refleksi dalam PTK mencakup analisis, sintesis, dan penilaian terhadap hasil pengamatan atas tindakan yang dilakukan.

Dalam penelitian ini, teknik yang digunakan untuk mengumpulkan data adalah sebagai berikut : Wawancara dilakukan kepada dosen pengampu pendidikan IPA SD secara langsung melalui pertanyaan lisan. Data yang diambil berupa pembelajaran apa saja yang diakukan sebelumnya, bagamana sikap ilmiah yang dimiliki mahasiswa sebelumnya. Kemudian bagaimana penerapan PJBL dalam peningkatan sikap ilmiah mahasiswa. Bentuk instrumennya berupa pedoman wawancara. Observasi yang dilakukan di kelas untuk mendapatkan gambaran secara langsung tentang tindak belajar dan tindak mengajar dengan menggunakan model pembelajaran project based learning menggunakan ceklist observasi. Angket dilakukan Pada penelitian yaitu untuk mengetahui sikap ilmiah mahasiswa yang dilakukan selama pembelajaran/perkuliahan

\section{Teknik Analisis Data}

Langkah-langkah yang perlu dilakukan dalam analisis data seperti ini adalah sebagai berikut:

1. Memilih data (reduksi data)

Pada langkah pemilihan data ini, peneliti memilih data yang relevan dengan tujuan perbaikan pembelajaran. Data yang tidak relevan dapat dibuang, dan jika dianggap perlu, guru dapat menambahkan data baru dengan mengingat kembali peristiwa atau fenomena yang terjadi selama pelaksanaan rencana tindakan.

\section{Mendeskripsikan data hasil temuan (memaparkan data)}

Pada kegiatan ini, guru peserta membuat deskripsi dari langkah yang yang dilakukan pada kegiatan reduksi data. Berbagai macam data penelitian tindakan yang telah direduksi perlu dipaparkan dengan menata rapi dalam bentuk narasi dengan dilengkapi grafik atau diagram (Herawati, 2009). Pemaparan data perlu dilakukan secara sistematis dan interaktif agar memudahkan pemahaman terhadap apa yang telah terjadi sekaligus memudahkan penarikan kesimpulan dan penentuan yang akan dilakukan selanjutnya. Dalam penelitian ini pemaparan data dapat dilihat pada pembahasan yang dapat dilihat berupa narasi proses pembelajaran serta pemaparan hasil belajar siswa dalam bentuk tabel atau grafik.

\section{Menarik kesimpulan hasil deskripsi}

Berdasarkan deskripsi yang telah dibuat pada langkah 2 tersebut, selajutnya dapat ditarik kesimpulan hasil pelaksanaan rencana tindakan yang telah dilakukan. Kesimpulan yang diambil dalam penelitian ini adalah kesimpulan yang mencangkup semua perubahan atau peningkatan pada diri peneliti, siswa serta situasi tempat penelitian dilakukan.

\section{HASIL DAN PEMBAHASAN}

Hasil penelitian mengenai sikap ilmiah mahasiswa PGSD UMS tahun ajaran 2016/2017 dimulai dari kondisi awal sampai dengan pelaksanaan siklus II pertemuan II dapat dilihat pada tabel berikut. 
Tabel 1. Sikap ilmiah Mahasiswa dari Awal Hingga Akhir

\begin{tabular}{|c|c|c|c|c|c|}
\hline \multirow{2}{*}{ indikator } & \multirow{2}{*}{ kondisi awal } & \multicolumn{2}{|c|}{ siklus 1} & \multicolumn{2}{|c|}{ siklus 2} \\
\hline & & pertemuan 1 & prtemuan 2 & pertemuan 1 & pertemuan 2 \\
\hline 1 & $49 \%$ & $51 \%$ & $53 \%$ & $65 \%$ & $74 \%$ \\
\hline 2 & $29 \%$ & $31 \%$ & $32 \%$ & $37 \%$ & $39 \%$ \\
\hline 3 & $26 \%$ & $30 \%$ & $30 \%$ & $35 \%$ & $38 \%$ \\
\hline 4 & $36 \%$ & $41 \%$ & $41 \%$ & $43 \%$ & $44 \%$ \\
\hline 5 & $28 \%$ & $34 \%$ & $35 \%$ & $36 \%$ & $40 \%$ \\
\hline 6 & $24 \%$ & $28 \%$ & $31 \%$ & $33 \%$ & $34 \%$ \\
\hline 7 & $17 \%$ & $17 \%$ & $27 \%$ & $33 \%$ & $38 \%$ \\
\hline 8 & $40 \%$ & $42 \%$ & $47 \%$ & $51 \%$ & $53 \%$ \\
\hline 9 & $19 \%$ & $19 \%$ & $19 \%$ & $30 \%$ & $42 \%$ \\
\hline 10 & $10 \%$ & $10 \%$ & $10 \%$ & $12 \%$ & $26 \%$ \\
\hline 11 & $45 \%$ & $48 \%$ & $48 \%$ & $51 \%$ & $53 \%$ \\
\hline 12 & $38 \%$ & $40 \%$ & $40 \%$ & $42 \%$ & $43 \%$ \\
\hline 13 & $58 \%$ & $60 \%$ & $60 \%$ & $60 \%$ & $63 \%$ \\
\hline 14 & $49 \%$ & $51 \%$ & $51 \%$ & $51 \%$ & $56 \%$ \\
\hline 15 & $19 \%$ & $19 \%$ & $33 \%$ & $35 \%$ & $42 \%$ \\
\hline 16 & $27 \%$ & $29 \%$ & $29 \%$ & $30 \%$ & $37 \%$ \\
\hline 17 & $30 \%$ & $30 \%$ & $30 \%$ & $30 \%$ & $37 \%$ \\
\hline 18 & $53 \%$ & $53 \%$ & $53 \%$ & $56 \%$ & $63 \%$ \\
\hline 19 & $47 \%$ & $47 \%$ & $47 \%$ & $51 \%$ & $53 \%$ \\
\hline 20 & $47 \%$ & $47 \%$ & $47 \%$ & $51 \%$ & $53 \%$ \\
\hline
\end{tabular}

Sikap ilmiah berkaitan erat dengan kegiatan IPA yang dilaksanakan di sekolah. Salah satu tujuan pengembangan sikap ilmiah adalah untuk menghindari munculnya sikap negatif dari siswa. Salah satu cara untuk mempertahankan dan meningkatkan sikap positif adalah membantu siswa mengembangkan apresiasi dalam sains memainkan peran dalam kehidupan sehari-hari. Mereka dapat mewujudkan hasil sains ketika sikap dan nilai praktis menjadi tujuan pengajaran (Martin, 2005). Sikap ilmiah mahasiswa PGSD UMS pada kondisi awal sangat rendah. Hal ini dikarenakan dosen masih menggunakan metode konvensional dan kurang memperhatikan aspek sikap ilmiah dalam pembelajaran IPA SD mahasiswa.

Pada pelaksanaan siklus I sikap ilmiah mahasiswa mengalami peningkatan. Tetapi peningkatan tersebut masih jauh dari indikator pencapaian, untuk itu diperlukan siklus berikutnya guna mencapai indikator yang telah ditetapkan. Pada pelaksanaan siklus II sikap ilmiah mahasiswa pada perkuliahan tentang pengenalan bagian-bagian mikroskop beserta fungsinya terus mengalami peningkatan. Dan sudah mencapai indikator pencapaian sebesar $85 \%$. Sehingga berdasarkan hasil tersebut maka indikator pencapaian sudah tercapai. Penerapan strategi perkuliahan Project based learning (PJBL) pada perkuliahan pengenalan bagian-bagian mikroskop beserta fungsinya sangat membantu 
dosen atau peneliti dalam upaya meningkatkan kualitas perkuliahan pada FKIP PGSD UMS. Hal ini dapat dibuktikan dengan adanya hasil penelitian yang telah dicapai.

Berdasarkan uraian di atas, sikap ilmiah dapat muncul ketika rasa ingin tahu siswa besar terhadap sesuatu yang belum diketahui. Guru sangat berperan dalam menumbuhkan sikap positif siswa, sehingga tujuan dan proses-proses pembelajaran yang dilaksanakan dapat menanamkan nilai-nilai positif bagi siswa. Dengan adanya media dan strategi yang inovatif suasana perkuliahan lebih kondusif, kreatif, menarik, dan menyenangkan. Mahasiswa merasa lebih termotivasi, perkuliahan menjadi lebih aktif dan optimal. Penerapan strategi perkuliahan Project based learning (PJBL) dengan perpaduan media perkuliahan membuat mahasiswa akan lebih cepat untuk memahami konsep serta materi yang diberikan dosen, dibandingkan dengan metode ceramah saja. Penggunaan media perkuliahan membawa pengalaman yang lebih berarti bagi pribadi mahasiswa. Penerapan strategi perkuliahan Project based learning (PJBL) dapat meningkatkan sikap ilmiah mahasiswa dalam belajar hal ini dilihat dari tecapai nya indikator-indikator sikap ilmiah. Selain itu penerapan strategi perkuliahan Project based learning (PJBL) juga dapat meningkatkan hasil belajar mahasiswa PGSD UMS. Dengan demikian dapat diketahui bahwa salah satu upaya untuk meningkatkan sikap ilmiah mahasiswa pada PGSD UMS yaitu dengan menggunakan strategi perkuliahan Project based learning (PJBL). Jadi melalui strategi perkuliahan Project based learning (PJBL) dapat meningkatkan sikap ilmiah mahasiswa PGSD UMS Tahun ajaran 2016/2017. Berdasarkan hasil dan pembahasan yang telah dipaparkan di atas maka hipotesis penelitian dapat diterima dan tujuan penelitian dapat tercapai.

\section{SIMPULAN DAN REKOMENDASI}

Hasil penelitian tindakan kelas yang dilakukan secara kolaboratif antara peneliti dan dosen kelas IIID PGSD FKIP UMS dapat disimpulkan sebagai bahwa Sikap ilmiah mahasiswa selama kegiatan pekuliahan di kelas mengalami peningkatan setelah dilakukan tindakan. Penerapan strategi pembelajaran Project Based Learning (PJBL) memberikan perubahan perilaku ke arah yang lebih baik. mahasiswa sangat menikmati pembelajaran yang diterapkan sehingga suasana kelas terlihat aktif dan kondusif. mahaiswa berani bertanya mengenai materi. mahasiswa sangat aktif dan antusias dalam belajar, mereka sangat menikmati praktikum serta bekerjasama dengan kelompoknya. mahasiswa juga sudah mau mentaati peraturan yang telah disepakati. sikap ilmiah mahasiswa menunjukkan Rasa ingin tahu, menghargai bukti, fleksibilitas dalam cara berpikir, berfikir kritis, kepekaan dalam menyelidiki lingkungan sekitar meningkat.

Peneliti berharap semoga penelitian ini dapat dilanjutkan bagi peneliti lain dengan menggunakan strategi pembelajaran dan materi yang berbeda dan lebih luas lagi. Agar proses pembelajaran di sekolah dapat berjalan lebih baik dan efektif.

\section{DAFTAR PUSTAKA}

Arends, R. 1. (2012). Learning To Teach (3rd ed.). New York: McGraw-Hill Education Bender. W.N. (2012). Project-based learning, 'nrousand Oaks, CA: Sage Published Borich, G.D. (2007). Effective teaching methods: research-based practice (6 ed.). Upper Saddle River, NJ: Pearson Education.

Carin, A.A., \& Sund, R.B. (1987). Teaching modem science third edition. Columbus: Charles E. Merrill Publishing Co. 
Harlen. W. (2000). Teaching, learning, and assesing science 5-12. London: A SAGE Publications Company.

Hartescu. 1. (2014). Providing technology support for project-based learning. The International Scientific Conference eLearning and Software for Education 3: 223229. Bucharest: "Carol I" National Defence University. Diambil dari http://scarch.proqucst.com/docvicw71534145(W3?accountid=31324

Hosnan. 2014. Pendekatan saintifik dan kontekstual dalam pembelajaran abad 21. Bogor: Ghalia Indonesia.

Joyce. B.. Calhoun, E., \& Hopkins. D. (2009). Models of learning tools for teaching $\left(3^{\text {rd }}\right.$ ed.). Two Penn Plaza, NY: Mc Grew Hill

Martin, R., Sexton, C., Franklin, T., et al. (2005). Teaching science for all children, inquiry methods for constructing understanding. New Y ork: Pearson Education, Inc

Moore, Alex. (2004). The Good Teacher: Dominnt discourses in teaching and teacher education. London: Routledgefalmer

Muresan, M. (2014). Project based collaborative learning for adult education. The International Scientific Conference eLearning and Software for Education 3: 303309. Bucharest: "Carol 1" National Defence University. dari http://scarch.proqucst.com/docvicw/7accounticU31324

Olasehinde. KJ., \& Olatoye, R.A. (2014). Scientific attitude, attitude to science and science achievement of senior secondary school students in Katsina State, Nigeria. Journal of Educational and Social Research.4, 445-452

Osborne, J. (2(X)3). Attitudes towards science: a review of the literature and its implications. Journal of Science Education, 25, 1049-1079

Patta Bundu. (2006). Penilaian keterampilan proses dun sikap ilmiah dalam pembelajaran SD. Jakarta: Depdiknas.

Pickens. B.C. ct. al (2012). Project hosed learning: enriching counselor education through real world learning. A PA style reference information. Article 15 (Halaman 3, volume 1). Diambil pada tanggal 12 Juli 2014 pukul 12.27 WIB dari http://www.COunseiing.org/library/

Pitafi, A.I., \& Farooq, M. (2012). Measurement of scientific attitude of secondary- school students in Pakistan. Academic Reasearch International. 2, 379-392.

Rusman. (2010). Model-model pembelajaran mengembangkan profesionalisme guru. Jakarta: Rajawali Press

Santrock, J.W. (2009). Psikologi pendidikan (Edisi J buku 2). (Terjemahan Diana Angelica). Avenue of the Americas. NY: McGraw-Hill. (Buku asli diterbitkan tahun 2008)

Santrock, John. W. (2004). Psikologi Pendidikan (Penerjemah Tri Wihowo). Jakarta: KENCANA prenada Media Group

Satrianawati. (2014). Model project based learning dalam tantangan pembelajaran sains abad XXI. Prosiding. Seminar Nasional Pendidikan Sains diselenggarakan oleh Program Studi Pendidikan Sains Pascasarjana UNY. tanggal 01 November 2014. Vol. 2 No. 1 Th. Jan-Des 2014. ISSN: 2339-1219

Schunk, D.H., Pintrich, P.H \& Meece, J.L.(2010). Motivation in Education Theory Research and Applications (3 ed.). New York: Pearson Edition,inc 
Westwood, P. (2008). What teachers need to know about teaching methods. Camberwell, VIC: Acer Press. 